\section{Measure Guideline: \\ Guide to Attic Air Sealing}

Joseph Lstiburek

Building Science Corporation

September 2014
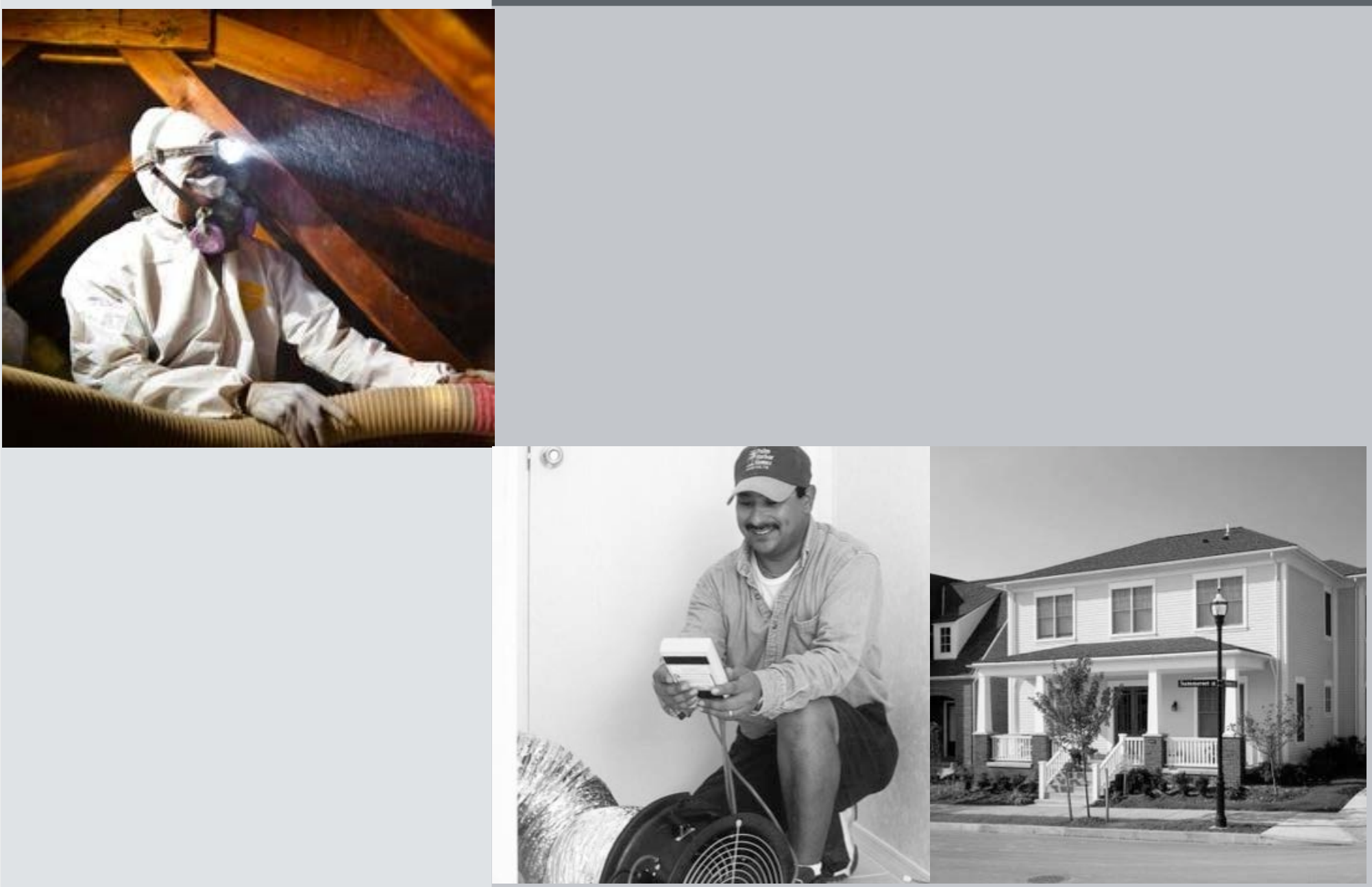


\section{NOTICE}

This report was prepared as an account of work sponsored by an agency of the United States government. Neither the United States government nor any agency thereof, nor any of their employees, subcontractors, or affiliated partners makes any warranty, express or implied, or assumes any legal liability or responsibility for the accuracy, completeness, or usefulness of any information, apparatus, product, or process disclosed, or represents that its use would not infringe privately owned rights. Reference herein to any specific commercial product, process, or service by trade name, trademark, manufacturer, or otherwise does not necessarily constitute or imply its endorsement, recommendation, or favoring by the United States government or any agency thereof. The views and opinions of authors expressed herein do not necessarily state or reflect those of the United States government or any agency thereof.

Available electronically at http://www.osti.gov/scitech

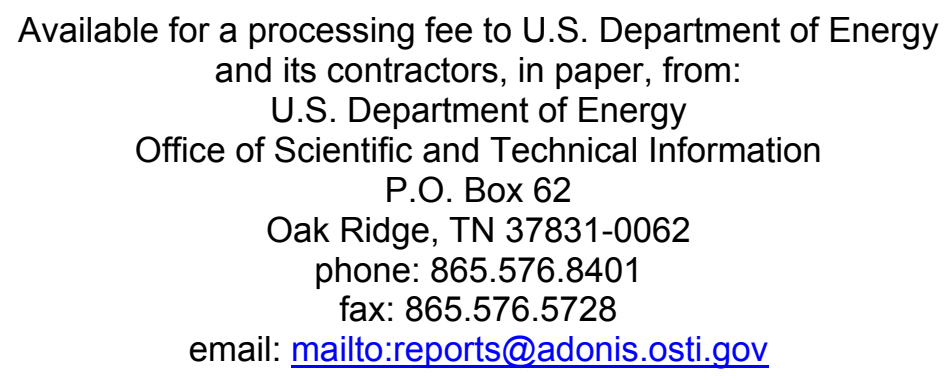

Available for sale to the public, in paper, from:

U.S. Department of Commerce

National Technical Information Service

5285 Port Royal Road

Springfield, VA 22161

phone: 800.553 .6847

fax: 703.605 .6900

email: orders@ntis.fedworld.gov

online ordering: http://www.ntis.gov/ordering.htm 


\title{
Measure Guideline: Guide to Attic Air Sealing
}

\author{
Prepared for:
}

The National Renewable Energy Laboratory

On behalf of the U.S. Department of Energy's Building America Program

Office of Energy Efficiency and Renewable Energy

15013 Denver West Parkway

Golden, CO 80401

NREL Contract No. DE-AC36-08GO28308

Prepared by:

Joseph Lstiburek

Building Science Corporation

3 Lan Drive, Suite 102

Westford, MA 01886

NREL Technical Monitor: Stacey Rothgeb

Prepared under Subcontract No. KNDJ-0-40337-05

September 2014 
The work presented in this report does not represent performance of any product relative to regulated minimum efficiency requirements.

The laboratory and/or field sites used for this work are not certified rating test facilities. The conditions and methods under which products were characterized for this work differ from standard rating conditions, as described.

Because the methods and conditions differ, the reported results are not comparable to rated product performance and should only be used to estimate performance under the measured conditions. 


\section{Contents}



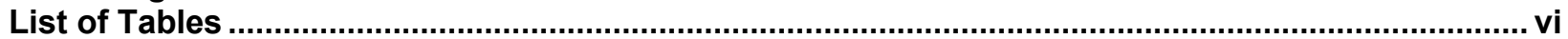

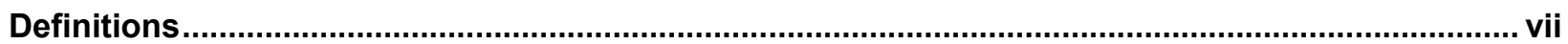

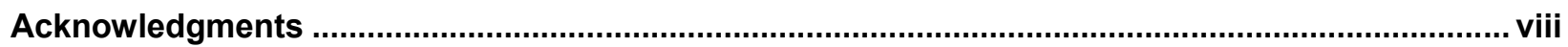

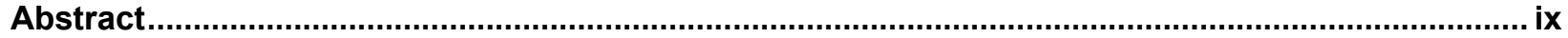

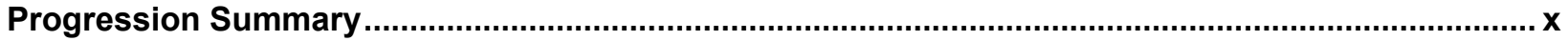

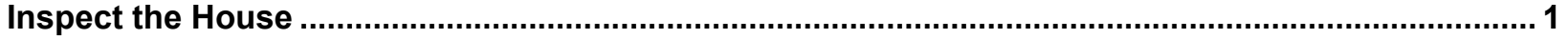

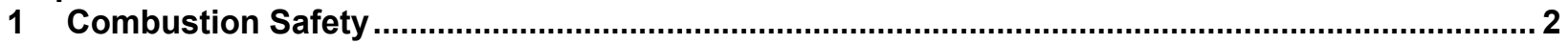

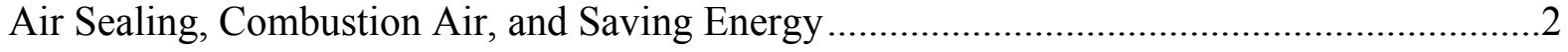

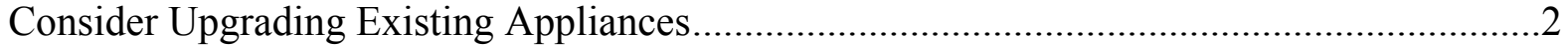

If the House Has Gas Appliances ............................................................................................... 3

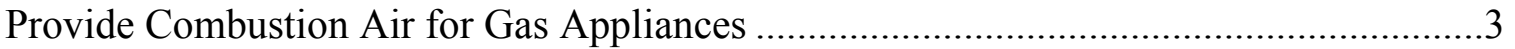

Clothes Dryers: Gas and Electric ............................................................................

Test Effectiveness of Combustion Air Supply......................................................

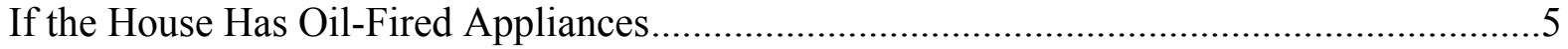

Provide Combustion Air for Oil Appliances ...............................................................6

Test Effectiveness of Combustion Air Supply..........................................................





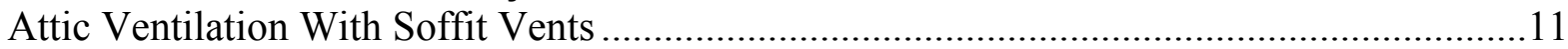

Attic Ventilation Without Soffit Vents ......................................................................... 12

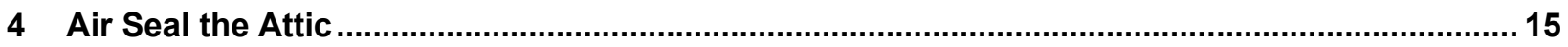

List of Attic Air Sealing Details ............................................................................. 15

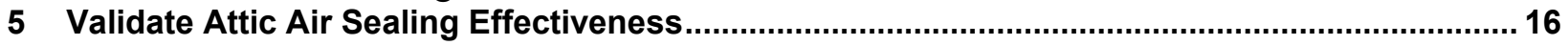

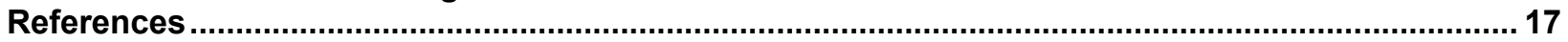

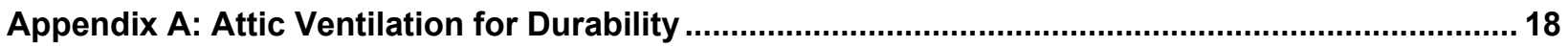

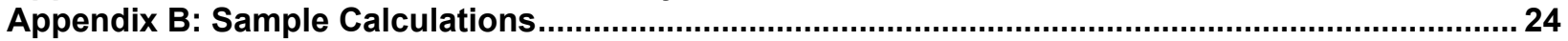




\section{List of Figures}

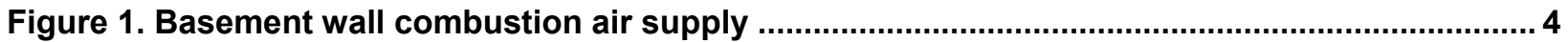

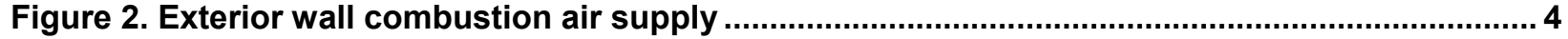



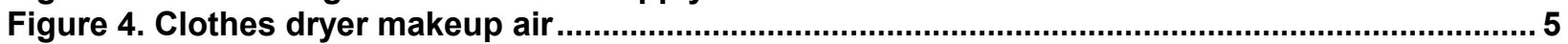

Figure 5. Basement wall combustion air supply ......................................................................... 7

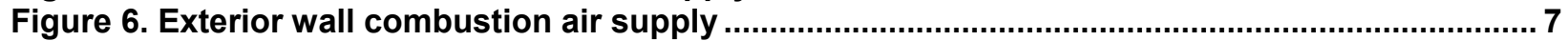

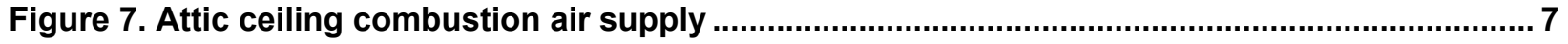

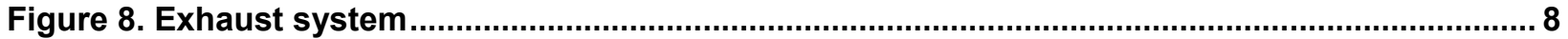

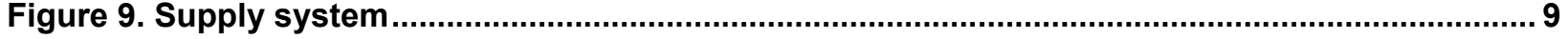

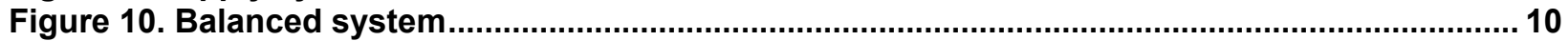

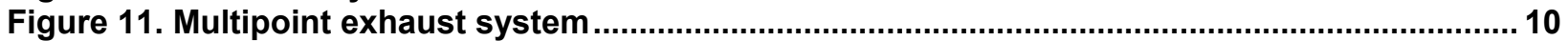

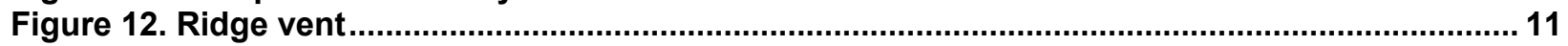

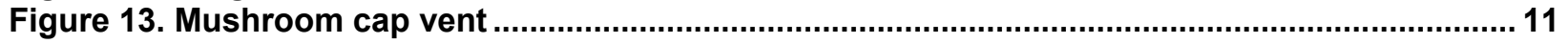

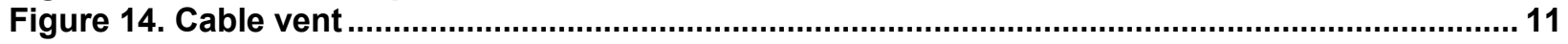

Figure 15. Continuous soffit attic ventilation — insulation baffles required in every bay............... 12

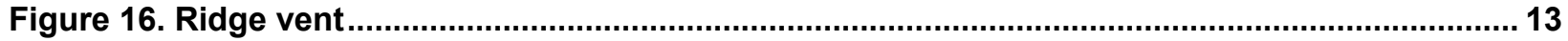



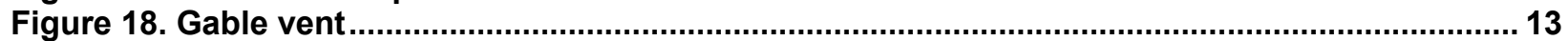



Figure 20. Vent baffle supported by fiber glass roll- even when there are no soffit vents............. 14

Unless otherwise noted, all figures were created by BSC.

\section{List of Tables}

Table 1. Gas-Fired Appliances_Single Opening to Outside .......................................................... 4

Table 2. Oil-Fired Appliances-Single Opening to Outside and Two Openings to the Inside........... 6

Unless otherwise noted, all tables were created by BSC. 


\section{Definitions}

$\begin{array}{ll}\text { CO } & \text { Carbon Monoxide } \\ \text { UL } & \text { Underwriters Laboratories } \\ \text { ERV } & \text { Energy Recovery Ventilator } \\ \text { HRV } & \text { Heat Recovery Ventilator } \\ \text { IFGC } & \text { International Fuel and Gas Code } \\ \text { Btu } & \text { British Thermal Unit } \\ \text { cfm } & \text { Cubic Feet per Minute } \\ \text { IRC } & \text { International Residential Code }\end{array}$




\section{Acknowledgments}

The author would like to acknowledge the funding and support of the U.S. Department of Energy's Building America Program. This guide is the product of a collaborative effort. Special thanks to Stephanie Finnegan, Bohdan Boyko, Ren Anderson, and Alex Lukachko. 


\section{Abstract}

The Guide to Attic Air Sealing provides information and specifications to the following groups:

- Home remodelers

- Builders

- Insulation contractors

- Mechanical contractors

- General contractors who have previously done remodeling

- Homeowners as a guide to the work that needs to be done.

The order of work to be done during home improvements is important. Health and safety issues must be addressed first and are more important than durability issues. And durability issues are more important than saving energy.

Even though the purpose of this guide is to save energy, health, safety, and durability should not be compromised by energy efficiency. Accordingly, combustion safety and ventilation for indoor air quality are addressed first. Durability and attic ventilation then follow. Finally, to maximize energy savings, air sealing is completed prior to insulating.

This guide is prescriptive based to minimize risks. Enhanced performance and greater energy savings are possible with performance-based approaches. Performance-based approaches should build on the measures and specifications contained in this guide.

Not all techniques can apply to all houses. Special conditions will require special action. Some homeowners will wish to do more than the important but basic retrofit strategies outlined by this guide. Where possible throughout the manual, links have been made to "performance" path solutions that require the judgment and experience of design professionals with specialist skills and experience.

For homeowners and contractors unfamiliar with working in attics, the following safety issues should be addressed:

- Be aware of head injury, especially nails in sheathing below roof.

- Wear proper personal protective equipment such as a mask for avoiding breathing in excessive dust and long sleeves to avoid skin irritation.

- Be prepared to walk among difficult obstacles along narrow walking boards or on ceiling joists with minimal hand holds. Do not step on insulation or gypsum board ceiling.

Be aware that you are working in a confined space and ensure that adequate ventilation is available. 


\section{Progression Summary}



\section{Do Not Proceed if:}

- The house attic has active knob and tube wiring.

- The house attic has vermiculite insulation.

- The house attic has bathroom fans vented into the attic.

- The house has a leaking roof.

- The house has an unvented kerosene heater or gas fireplace.
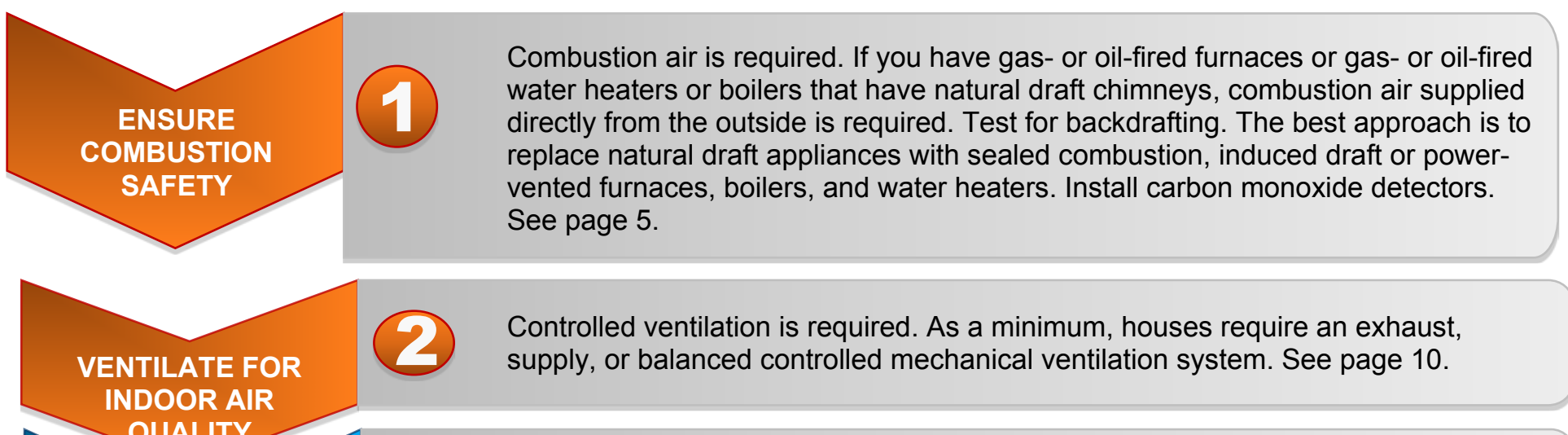

Attic ventilation is required. All roofs must be vented according to the applicable building code. See page 12 .

\section{VENTILATE THE}

ATTIC FOR

DURABILITY

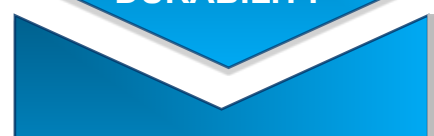

Follow the details provided in this guide. See page 15.

AIR SEAL THE ATTIC

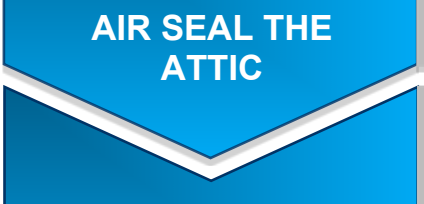

THEN INSULATE
Install according to manufacturer's instructions, including all safety, performance and quality assurance requirements. 


\section{Inspect the House}

Before any air sealing work is done, inspect the work area. Check first for active knob and tube wiring, vermiculite insulation, bathroom fans vented into attics, leaking roofs, unvented kerosene heaters or gas fireplaces, and attic flooring.

Stop work-do not proceed:

IF the house attic has active knob and tube wiring.

IF the house attic has vermiculite insulation.

IF the attic has bathroom fans vented into the attic.

IF the house has a leaking roof.

IF there is an unvented kerosene heater or gas fireplace.

IF the attic floor has floorboards or other floor sheathing.
Note on vermiculite: This insulation may be contaminated with asbestos. For more information, see EPA (2014).
THEN the house must be rewired prior to the attic being air sealed and insulated.

THEN professional advice should be obtained. The vermiculite insulation may contain asbestos and must be tested prior to the attic being air sealed and insulated. Contact your State Department of Health.

THEN the bathroom fans must be vented to the outside prior to the attic being air sealed and insulated.

THEN the leaking roof must be fixed prior to the attic beina air sealed and insulated.

THEN the unvented heater or fireplace must be vented or removed prior to the attic being air sealed and insulated.

THEN professional advice should be sought to determine whether the flooring serves as a structural function. If it does, the function must be replicated by other means before the flooring is removed to allow access for air sealing and insulating.

Check next for combustion appliances, controlled ventilation, and required attic ventilation. The following health, safety, and durability issues must be addressed 


\section{Combustion Safety}

If you have gas- or oil-fired furnaces or gas- or oilfired water heaters that have natural draft chimneys, combustion air supplied directly from the outside is required. If natural draft gas or oil appliances are present and a dedicated source of combustion air supply from the outside is not present, then a qualified mechanical or plumbing contactor in the state must be engaged to provide this source of combustion air. Carbon monoxide (CO) detectors are required to be installed if the house has combustion appliances.

The best approach is to replace natural draft appliances with sealed combustion, induced draft, or power-vented furnaces, boilers, and water heaters. They are significantly more energy efficient than natural draft appliances and, when installed according to manufacturers' installation instructions, they do not require a duct supplying outside combustion air as described here.

\section{Air Sealing, Combustion Air, and Saving Energy}

Energy is saved when holes between conditioned areas and unconditioned attics are sealed even if a necessary hole is then added to supply combustion air. The logic is both intuitive and counterintuitive. First, in most houses the surface area of holes sealed in the attic will be much greater than the surface area of the hole added to provide combustion air. The house, therefore, ends up with fewer holes.

Second, not all holes are alike. Holes up high leak more air than holes down low. This is because houses are like hot air balloons that are too heavy to leave the ground. A hole at the bottom of the hot air balloon does not matter much, but a hole at the top of the hot air balloon matters a great deal. Sealing a hole up high in an attic and then adding a hole of equal size down near a furnace actually reduces air leakage and saves energy. There are some important openings that should not be sealed. Combustion air ducts and soffit, ridge, and gable vents are all intentional openings that must be kept open to air movement in order to work properly.

Most importantly, sealing holes in attics makes chimneys work better. A leaky attic ceiling acts like a chimney, and this "attic ceiling chimney" competes with the real chimney for the same air.

Air sealing the leaky attic ceiling also reduces the "suction" of the house on the ground under the house so fewer contaminants, such as radon and other soil gases, are drawn into the house. The more air that leaves the top of a house, the more air is drawn (or sucked) in at the bottom of a house. Sealing the top of a house reduces the entry of contaminants and air at the bottom of a house, even if a hole is present at the bottom of the house.

\section{Consider Upgrading Existing Appliances}

The best approach to combustion safety is to replace natural draft appliances with sealed combustion, induced draft or power-vented furnaces, boilers, and water heaters. These types of 
appliances are significantly more energy efficient than natural draft appliances and when installed according to manufacturers' installation instructions they do not require a duct supplying outside combustion air as described here.

\section{If the House Has Gas Appliances}

Combustion safety: For more information, see EPA 2012; www.epa.gov/iaq/homes/hipcombustion.html)
Gas-fired furnaces, boilers, and water heaters that have natural draft chimneys require combustion air. It should be supplied from the outside by a duct. If these ducts are not sized correctly or if they are blocked, this can result

in incomplete combustion of the fuel and can lead to backdrafting. Backdrafting occurs when hazardous exhaust gases enter into the house rather than exit through the flue. The requirements for gas appliances are slightly different than those for oil appliances. Houses that have appliances with natural draft chimneys, even if combustion air is supplied directly from the outside, should be tested for backdrafting (see ICC 2009b).

Additionally, if the house has combustion appliances, $\mathrm{CO}$ detectors complying with Underwriters Laboratories (UL) 2034 are required in close proximity to the combustion appliances and outside each separate sleeping area in the immediate vicinity of the bedrooms (ICC 2009c).

\section{Provide Combustion Air for Gas Appliances}

A duct supplying outside combustion air is required for all natural draft gas-fired furnaces and natural draft gas-fired water heaters (see Figure 1 through Figure 3). The size of this duct is determined by the sum of the Btu input into both appliances and Table 1. See ICC (2009d).

Homes may have more than one combustion air zone. In other words, combustion appliances may be located in more than one part of a house, in different areas. Each zone needs to be treated separately.

Combustion air openings must be located away from combustion air exhaust vents if there is a power vented appliance along with a standard draft hood appliance. 




Figure 1. Basement wall combustion air supply

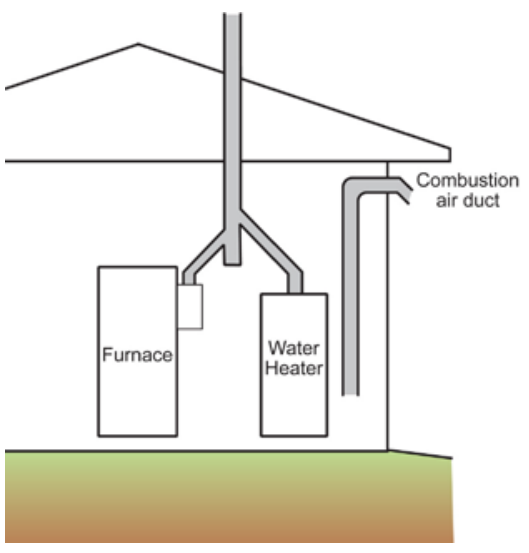

Figure 2. Exterior wall combustion air supply

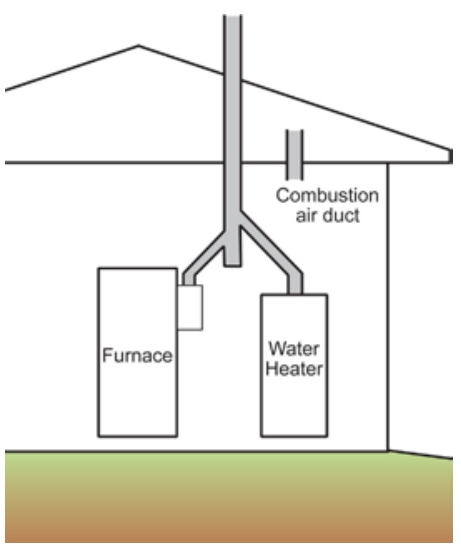

Figure 3. Attic ceiling combustion air supply

Table 1. Gas-Fired Appliances-Single Opening to Outside

\begin{tabular}{c|c|c|c}
\hline $\begin{array}{c}\text { Total Input Rating of All } \\
\text { Appliances in Space } \\
\text { (Btu) }\end{array}$ & \multicolumn{2}{|c}{ One Exterior Opening } \\
\hline From & To & $\begin{array}{c}\text { Free Area } \\
\text { (in. }{ }^{2} \text { ) }\end{array}$ & $\begin{array}{c}\text { Duct } \\
\text { Diameter } \\
\text { (in.) }\end{array}$ \\
\hline 0 & 23,999 & 7 & 3 \\
\hline 24,000 & 38,999 & 13 & 4 \\
39,000 & 59,999 & 20 & 5 \\
60,000 & 86,999 & 28 & 6 \\
87,000 & 116,999 & 38 & 7 \\
117,000 & 152,999 & 50 & 8 \\
153,000 & 191,999 & 64 & 9 \\
192,000 & 236,999 & 79 & 10 \\
\hline
\end{tabular}

NOTES: Openings to outside shall be located within $12 \mathrm{in.} \mathrm{of} \mathrm{top} \mathrm{of} \mathrm{enclosure.} \mathrm{The} \mathrm{"top} \mathrm{of} \mathrm{the} \mathrm{enclosure"} \mathrm{refers} \mathrm{to}$ the ceiling of the room the appliances are located within.

The net free areas must take into account louvers and grilles if they are installed. Assume $75 \%$ free area for metal and $25 \%$ for wood if the specific louver/grille dimensions are unknown. 


\section{Clothes Dryers: Gas and Electric}

Clothes dryers are powerful exhaust devices that typically exhaust $150 \mathrm{cfm}$ of interior air to the outside (ICC 2006a, 2006b). A makeup air opening of $100 \mathrm{in}^{2}$ is necessary for gas dryers and is recommended for electric dryers where dryers are located in rooms or closets (see Figure 4).



Figure 4. Clothes dryer makeup air

Where gas clothes dryers are located in the same space as gas furnaces and water heaters, the Btu input of the gas clothes dryer should be added to the Btu input of natural draft gas-fired furnaces and natural draft gas-fired water heaters when sizing the duct supplying outside combustion air using Table 1.

\section{Test Effectiveness of Combustion Air Supply}

The effectiveness of the method of supplying combustion air should be determined by the procedure contained in Appendix D of the 2009 International Fuel Gas Code (ICC 2009b). Chimney draft is checked with all exhaust appliances such as dryers, kitchen fans, and bathroom fans operating and also with the air handling unit fan(s) operating and interior doors closed.

\section{If the House Has Oil-Fired Appliances}

Oil-fired furnaces, boilers, and water heaters that have natural draft chimneys require combustion air. It should be supplied from the outside by a duct. If these ducts are not sized correctly or if they are blocked this can result in incomplete combustion of the fuel and can lead to

Combustion safety: For more information, see EPA 2012; www.epa.gov/iaq/homes/hipcombustion.html) backdrafting. Backdrafting occurs when hazardous exhaust gasses enter into the house rather than exit through the flue. The requirements for gas appliances are slightly different than those for oil appliances. Houses with appliances with natural draft chimneys should, even if combustion air is supplied directly from the outside, be tested for backdrafting. Combustion air 
openings must be located away from combustion air exhaust vents if there is a power vented appliance along with a standard draft hood appliance (ICC 2009b).

Additionally, if the house has combustion appliances, CO detectors complying with UL 2034 are required in close proximity to the combustion appliances and outside each separate sleeping area in the immediate vicinity of the bedrooms (ICC 2009c).

\section{Provide Combustion Air for Oil Appliances}

A duct supplying outside combustion air is required for all natural draft oil-fired furnaces and natural draft oil-fired water heaters. The size of this duct is determined by the sum of the Btu input into both appliances and Table 2. In addition, for oil-burning appliances, two additional openings to the inside are required if the oil-burning appliances are enclosed in a room (NFPA 2006). The size of these two openings can also be found in Table 2. If the oil-burning appliances are not contained in a separate room, then these two openings to the interior are not required. For example, if an oil-fired furnace and oil-fired water heater are located in an open basement, then no additional openings to the interior are required (see Figure 5 through Figure 7).

\section{Table 2. Oil-Fired Appliances-Single Opening to Outside and Two Openings to the Inside}

\begin{tabular}{|c|c|c|c|c|}
\hline \multicolumn{2}{|c|}{$\begin{array}{c}\text { Total Input Rating of All } \\
\text { Appliances in Space } \\
\text { (Btu) }\end{array}$} & \multicolumn{2}{|c|}{ One Exterior Opening } & \multirow{2}{*}{$\begin{array}{c}\begin{array}{c}\text { Two Interior } \\
\text { Openings }\end{array} \\
\begin{array}{c}\text { Free Area of } \\
\text { Each Opening } \\
\left(\text { in. }{ }^{2}\right)\end{array}\end{array}$} \\
\hline From & To & $\begin{array}{l}\text { Free Area } \\
\left.\quad \text { (in. }^{2}\right)\end{array}$ & $\begin{array}{c}\text { Duct Diameter } \\
\text { (in.) }\end{array}$ & \\
\hline 0 & 39,999 & 7 & 3 & 40 \\
\hline 40,000 & 64,999 & 13 & 4 & 65 \\
\hline 65,000 & 99,999 & 20 & 5 & 100 \\
\hline 100,000 & 144,999 & 28 & 6 & 145 \\
\hline 145,000 & 194,999 & 38 & 7 & 195 \\
\hline 195,000 & 254,999 & 50 & 8 & 255 \\
\hline 255,000 & 319,999 & 64 & 9 & 320 \\
\hline 320,000 & 394,999 & 79 & 10 & 395 \\
\hline
\end{tabular}

Notes: The net free areas must take into account louvers and grilles if they are installed. Assume $75 \%$ free area for metal and $25 \%$ for wood if the specific louver/grille dimensions are unknown

Homes may have more than one combustion air zone. In other words, combustion appliances may be located in more than one part of a house - in different areas. Each zone needs to be treated separately.

Combustion air openings must be located away from combustion air exhaust vents if there is a power vented appliance along with a standard draft hood appliance. 


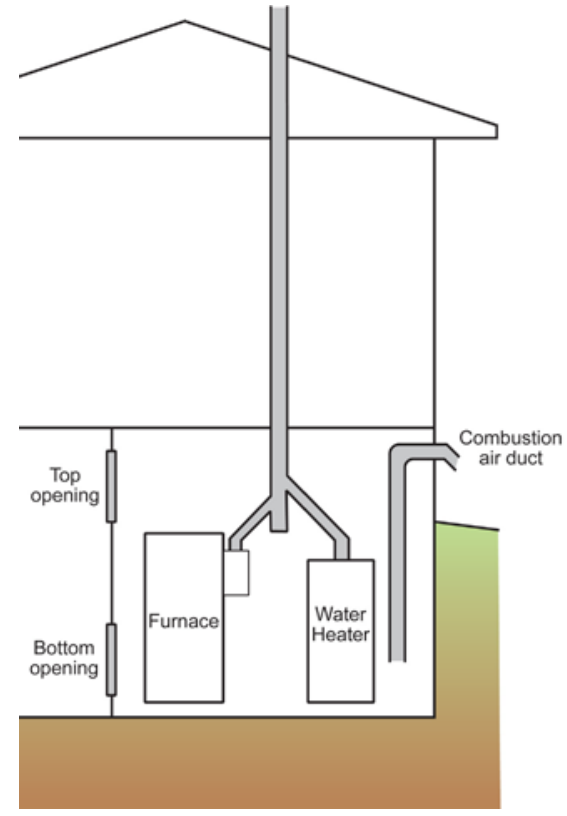

Figure 5. Basement wall combustion air supply

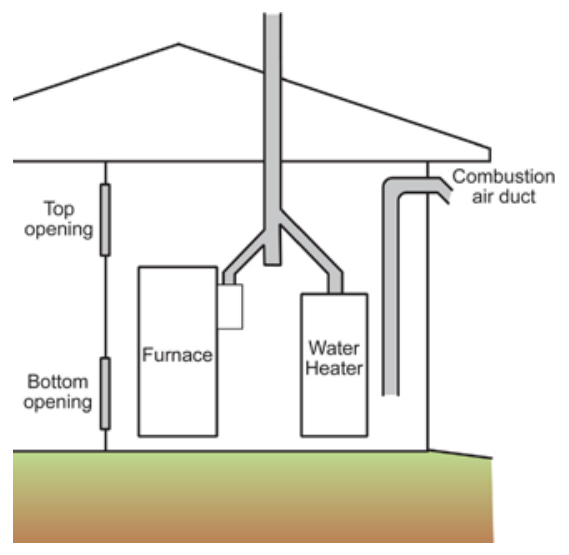

Figure 6. Exterior wall combustion air supply

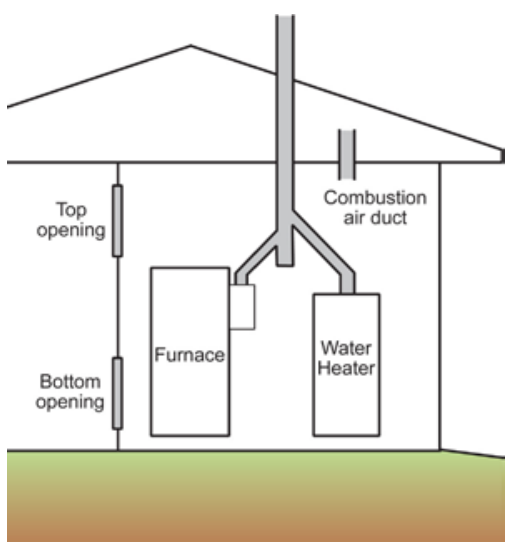

Figure 7. Attic ceiling combustion air supply

\section{Test Effectiveness of Combustion Air Supply}

The effectiveness of the method of supplying combustion air should be determined by the procedure contained in Appendix D of the 2009 International Fuel Gas Code (ICC 2009b). Chimney draft is checked with all exhaust appliances such as dryers, kitchen fans, and bathroom fans operating and also with the air handling unit fan(s) operating and interior doors closed. 


\section{Controlled Ventilation for Indoor Air Quality}

At a minimum, houses require an exhaust, supply, or balanced controlled mechanical ventilation system (ASHRAE 2010). If a controlled mechanical ventilation system is not present, one should be installed by a qualified contractor.
Definition of Controlled Ventilation: The process of supplying outdoor air to or removing indoor air from a dwelling by a fan or fans.

All houses require small amounts of controlled mechanical ventilation. This can be accomplished with an exhaust system, a supply system, or a balanced system.

For ventilation systems to ventilate they must be run. Continuous operation of a ventilation system typically controls indoor contaminants more effectively than infrequent operation. Proper sizing is important (see sidebar definition and example). Undersizing and infrequent operation can lead to elevated levels of indoor contaminants. Oversizing can lead to excessive energy consumption and elevated levels of interior moisture in humid climates. Oversized ventilation

Definition: Mechanical ventilation flow rates (exhaust or supply) are determined as follows:

Flow Rate $=$ Occupant Rate + Building Rate Occupant Rate $=($ no. of bedrooms +1$) \times 7.5 \mathrm{cfm}$ Building Rate $=$ Occupied Floor Area $\times 0.01 \mathrm{cfm}$ Example: A three-bedroom house with a floor area of $2,000 \mathrm{ft}^{2}$ requires a mechanical ventilation flow rate of $50 \mathrm{cfm}$

Occupant Rate $=(3+1) \times 7.5=30 \mathrm{cfm}$

Building Rate $=2,000 \times 0.01=20 \mathrm{cfm}$

Flow Rate $=30+20=50 \mathrm{cfm}$ systems that run continuously should be avoided. Excessive ventilation is humid climates is not recommended as it can lead to elevated interior levels of moisture.

A properly sized bathroom fan that is vented to the exterior that is controlled by a timer or operated continuously is one of the acceptable options for an acceptable exhaust system (Figure 8).

Excessive ventilation is humid climates is not recommended as it can lead to elevated interior levels of moisture.

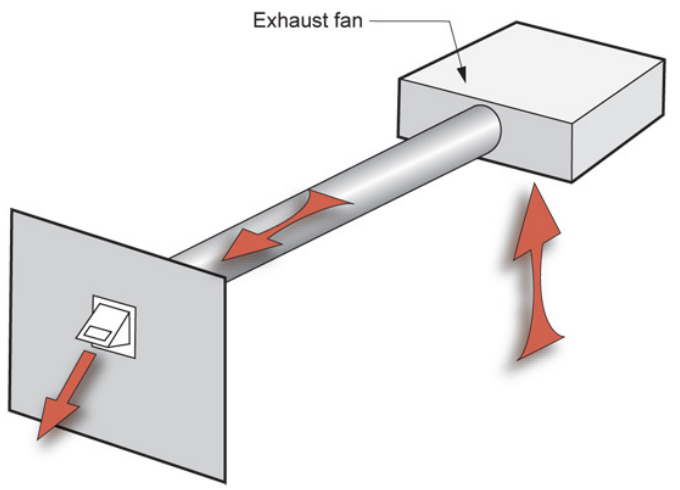

Figure 8. Exhaust system 
An acceptable supply system is a properly sized outside air duct connected to the furnace or air conditioner (Figure 9). The outside air duct requires a volume damper and a motorized damper and controller to prevent overventilation and underventilation. When the furnace or air conditioner fan operates, outside air is brought into the house and distributed.

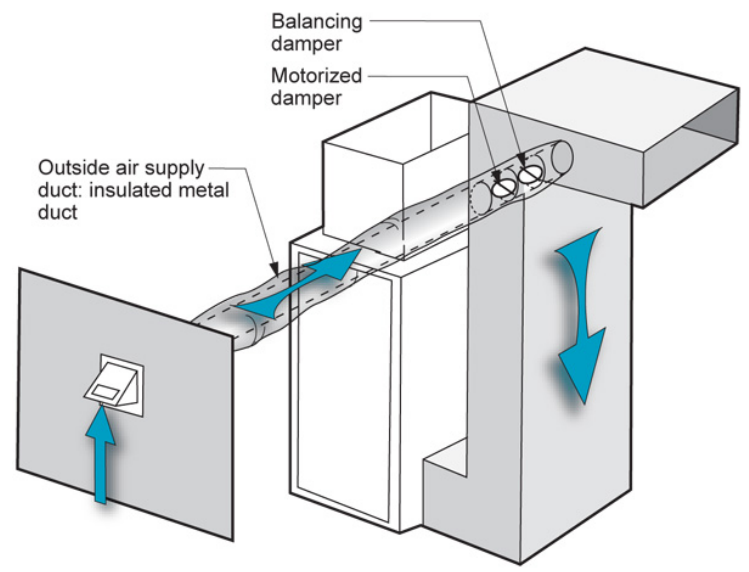

Figure 9. Supply system

Definition of Volume Damper: A volume damper or a balancing damper is a device that adjusts flow rate-a flap or iris that can be closed off to reduce flow-or opened up to increase flow. These types of dampers are usually set once manually.

Definition of Motorized Damper: A motorized damper is a device that opens and closes via an electronic control such as a timer or thermostat or ventilation stat or humidistat. The damper should also be tied to compressor operation.
An acceptable balanced system is a properly sized air-to-air heat exchanger/heat recovery ventilator (HRV) or an energy recovery ventilator (ERV) that both exhausts inside air to the exterior and supplies outside air to the interior at approximately the same rate (Figure 10). Such systems are typically designed to operate on a timer or continuously. Air-to-air heat exchangers or HRVs are recommended for cold climates and dry climates. HRVs do not transfer moisture between incoming and outgoing streams of air.

ERVs are recommended for humid climates. ERVs transfer moisture between the incoming and outging streams of air. 


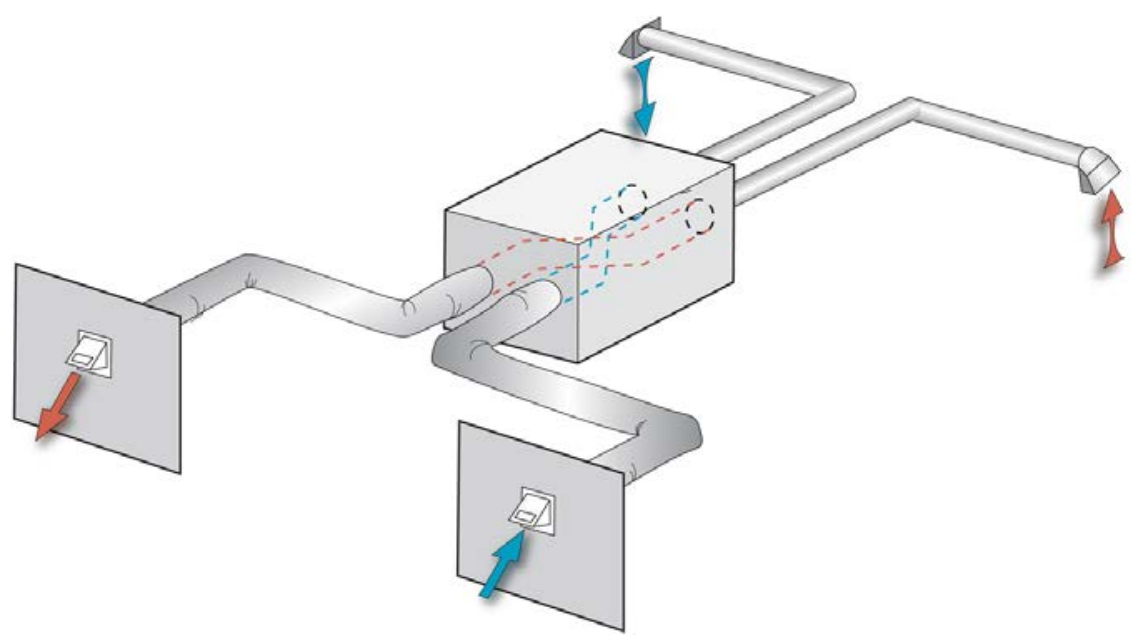

Figure 10. Balanced system

Another acceptable exhaust system is a properly sized multipoint exhaust system that is vented to the exterior. Such systems are typically designed to operate on a timer or continuously.

A typical configuration for a multipoint exhaust system involves exhausting from bathroom and wet areas (Figure 11).



Figure 11. Multipoint exhaust system 


\section{Ventilate the Attic for Durability}

All roofs must be vented according to the applicable building code. If the roof is not vented according to the applicable building code then a qualified contractor in the state should be engaged to install the necessary venting.

House attics can be designed and constructed and renovated to be unvented. However, this requires specialized knowledge. Qualified individuals should be consulted when implementing this type of approach and the respective sections of the applicable building code governing the construction of unvented attics should be followed.

\section{Attic Ventilation With Soffit Vents}

Attic ventilation is an important factor in controlling moisture in roof sheathing and structural members in most types of housing. It therefore significantly impacts the durability of the typical house. All roofs must be vented according to the applicable building code. If the roof is not vented according to the applicable building code, then a qualified contractor in the state should be engaged to install the necessary venting (ICC 2009e).

For attic ventilation to be effective, outside air should enter the attic low at the attic perimeter and exit high near the attic ridge — intake air inlets down low—exhaust air outlets up high.

It is important to provide an air gap at the soffit/eave area to control the accumulation of moisture at the roof sheathing over the soffit/eave area. This air gap can be used with soffit vents to provide the inlet for attic intake ventilation air. Continuous soffit vents work best and are recommended.

Various types of outlets (ridge vents, mushroom cap vents and upper gable end vents) can be matched with soffit inlets (see Figure 12 through Figure 14).

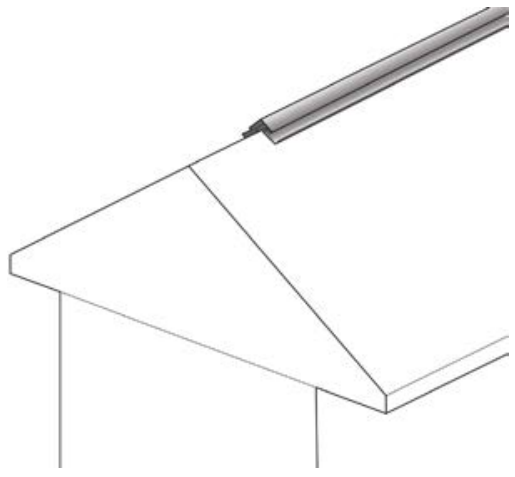

Figure 12. Ridge vent

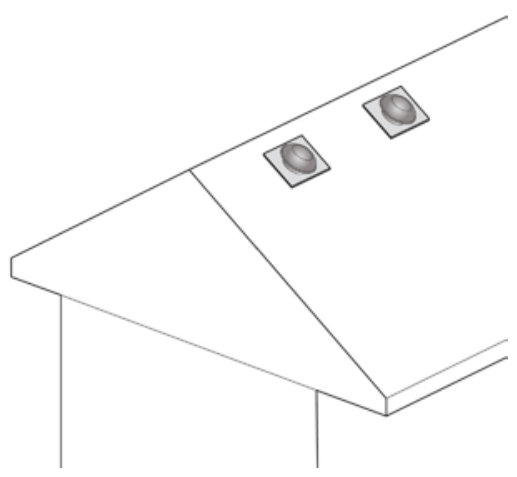

Figure 13. Mushroom cap vent

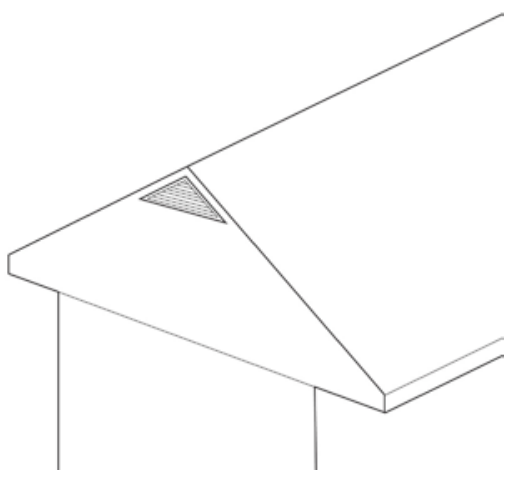

Figure 14. Cable vent 
The size of the vents should be determined by the applicable building code. Most codes require that roofs be vented where the net free ventilating area be not less than $1 / 300$ of the area of the space to be ventilated - ideally with the vent area of the low inlet vents being equal to the vent area of the high outlet vents - in other words the vent area split equally high and low. If it is not possible to split the vent area equally between high and low, the low vents are more important. It is better to have a greater area of vents down low than vents located up high. Excessive vents up high can lead to suction in the attic resulting in the drawing of air out of the top of the house. Makeup air for attic ventilation should come from the outside not from the house.

Where radiant barriers are installed below a roof deck, it is necessary to vent the attic space both above and below the radiant barrier (except where the radiant barrier is directly attached to the roof deck). In addition the radiant barrier must have openings at vent openings such as ridge vents or off-ridge vents. Radiant barriers need an adjacent airspace to function- 1 in. is the recommended minimum.

Soffit vents must be used in conjunction with ridge vents or mushroom cap vents or gable vents (Figure 15).

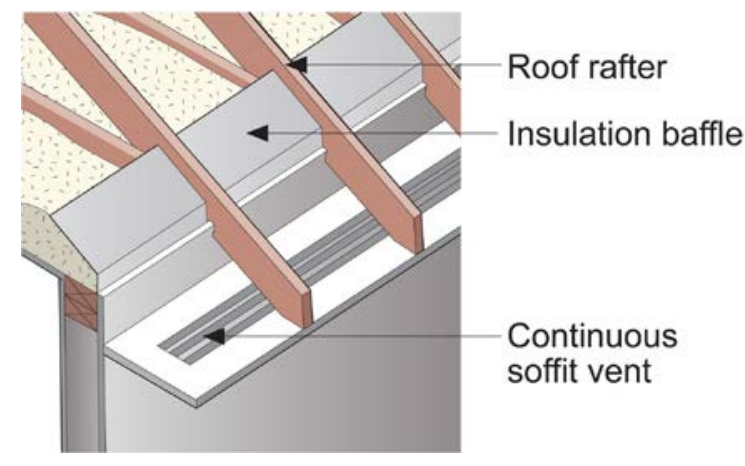

\section{Figure 15. Continuous soffit attic ventilation- insulation baffles required in every bay}

\section{Attic Ventilation Without Soffit Vents}

Not all roofs can be vented with soffit vents providing the necessary inlet for attic intake ventilation air. Some roofs have minimal or nonexistent overhangs or sufficient soffit area for soffit vent installation.

If soffit venting is not possible then an alternative method of providing intake air inlets low near the roof perimeter should be provided. Two recommended methods are low gable vents located near the attic ceiling (but above the top of the level of the attic ceiling insulation) and "eyebrow" vents that can be located on the top of the sloping roof surface near the soffit area/eave. For attic ventilation to be effective outside air should enter the attic low at the attic perimeter and exit high near the attic ridge - intake air inlets down low — exhaust air outlets up high (ICC 2009e). 
Even without soffit ventilation it is important to provide an air gap at the soffits/eave area to control the accumulation of moisture at the roof sheathing over the soffit/eave area.

Various types of outlets (ridge vents, mushroom cap vents, and upper gable end vents) can be matched with low gable vents and "eyebrow" inlets (see Figure 16 through Figure 19).

Homes without accommodation for ventilation openings at the soffit or eave, shall have a net free ventilating area of not less than 1/150 of the area of the ventilated attic/roof space.

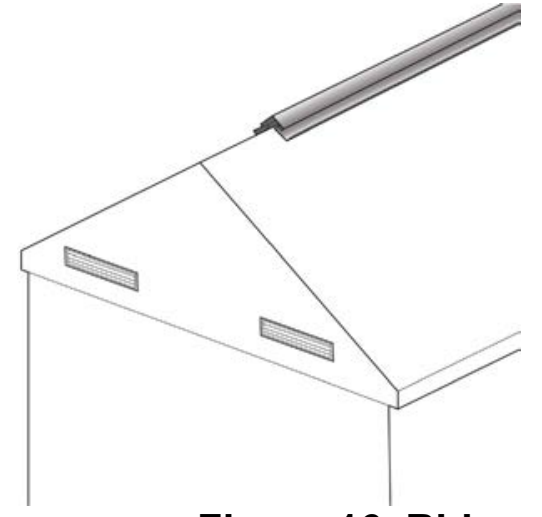

Figure 16. Ridge vent

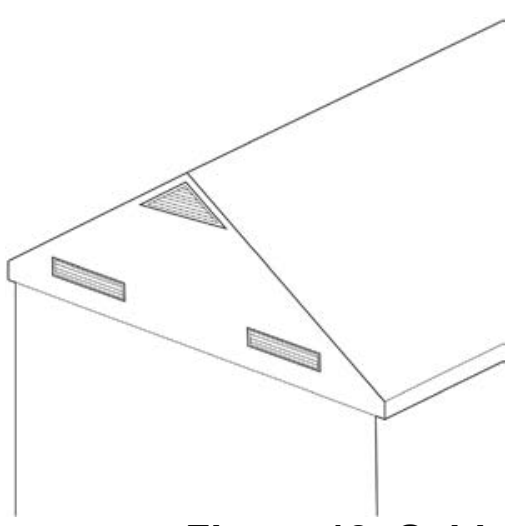

Figure 18. Gable vent

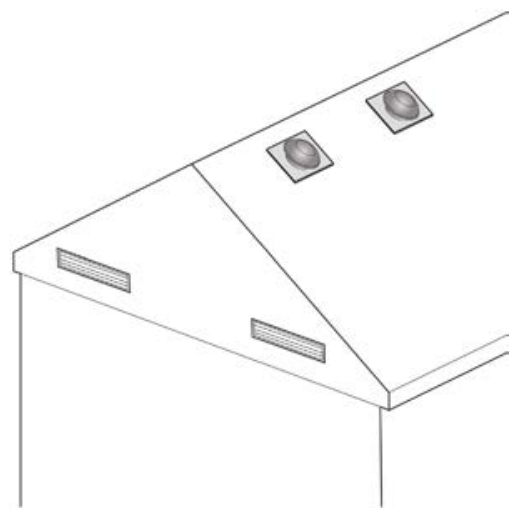

Figure 17. Mushroom cap vent

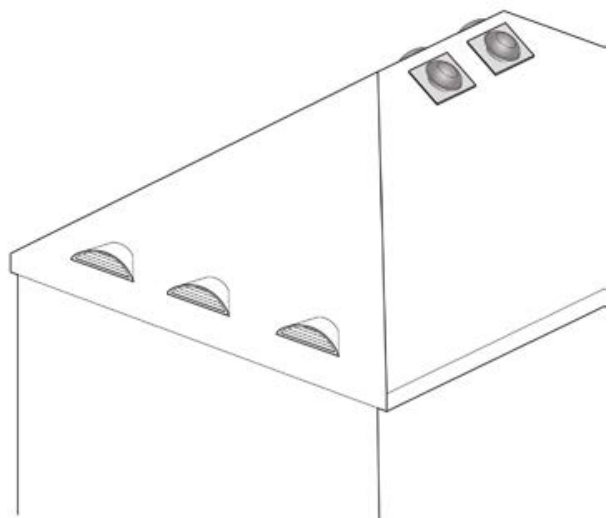

Figure 19. Hip roof with eyebrow vents

The size of the vents should be determined by the applicable building code. Most codes require that roofs be vented where the net free ventilating area be not less than 1/300 of the area of the space to be ventilated - ideally with the vent area of the low inlet vents being equal to the vent area of the high outlet vents - in other words the vent area split equally high and low.

If it is not possible to split the vent area equally between high and low, the low vents are more important. It is better to have a greater area of vents down low than vents located up high. Excessive vents up high can lead to suction in the attic resulting in the drawing of air out of the top of the house (see Figure 20). Makeup air for attic ventilation should come from the outside, not from the house. 


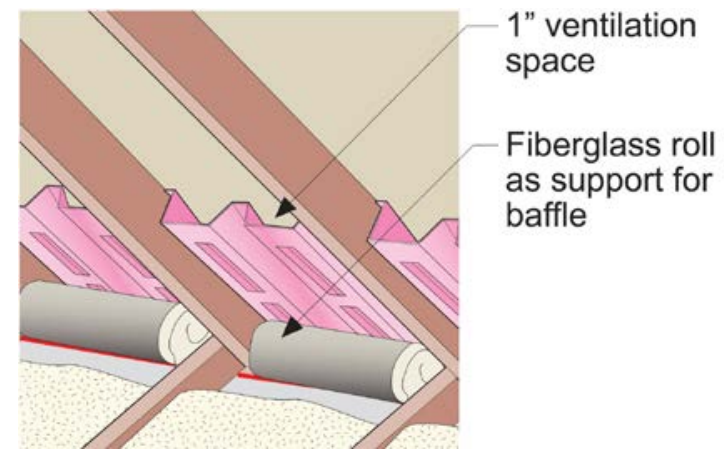

Figure 20. Vent baffle supported by fiber glass rolleven when there are no soffit vents

The air gap provided by the vent baffle provides redistribution of moisture to the main body of the attic, even when there are no soffit vents. The vent baffle should be of plastic or of foam construction — cardboard vent baffles should be avoided where baffles are needed in unvented soffit/eave assemblies. 


\section{$4 \quad$ Air Seal the Attic}

Once the issues identified above have been addressed, proceed to develop the attic air sealing work plan. The work plan must account for steps needed for creating access to areas that need to be inspected and areas that need to be air sealed. For example, if a large volume

Definition of Attics: The space between the underside of the roof deck sheathing and the topside of the top story ceiling. This space does not include cathedral ceilings. of belongings is stored in the attic, the work plan may need to address relocation and temporary storage for these items. Also, flooring or sheathing, if present, at the attic floor will need to be removed before air sealing can proceed. However, where the attic flooring or floor sheathing is providing a structural function that function will need to be replicated (e.g. through the installation of collar ties) before the attic flooring or floor sheathing is removed. A sample work plan can be found in Appendix A.

Other guides for air sealing are available. The EPA Duct Sealing brochure provides important information for houses with ductwork and other mechanical system components located in the attic. If applicable, information from the other guides should be considered when developing the attic air sealing work plan.

\section{List of Attic Air Sealing Details}

Attic access

Attic hatch, access panel

Pull down stair opening

Framing

Balloon-framed gable wall

18,19

Gable truss

Multi-family common wall

Dropped soffits (bulkheads, arches, cabinet bonnets) 22

Exterior top plate at soffit

23,24

Kneewalls

25,26

Two-story wall

27,28

Mechanical and electrical penetrations

Bath fan

Chimney chase - masonry

30

Chimney chase - metal pipe

31,32

Duct boot

Electrical box

Plumbing stack

Recessed can ceiling light

37

Rigid or flex duct and chase

38,39

Top plate joints and penetrations

40 (electrical/plumbing) 


\section{$5 \quad$ Validate Attic Air Sealing Effectiveness}

Once the air sealing is complete, verify that the work has been done according to the air sealing guide recommendations. One method to validate the work is to perform a blower door test by depressurizing the building and then locating the air leaks (The Energy Conservatory 2012).
Definition of Blower Door: A machine used to test the airtightness of buildings or of smaller spaces within buildings. A blower door is mounted in an opening such as a window or door and then uses a fan to pressurize or depressurize the measured space. The more airtight the space, the less air is needed from the blower door fan to create a change in air pressure. 


\section{References}

ASHRAE (2010). Standard 62.2 - 2010: Ventilation and Acceptable Indoor Air Quality in Low Rise Residential Buildings. Atlanta, GA: American Society of Heating, Refrigerating and AirConditioning Engineers.

EPA (2012). Indoor Air Quality in Homes. Washington, D.C.: U.S. Environmental Protection Agency. http://www.epa.gov/iaq/homes/hip-combustion.html. Accessed August 2014.

EPA (2014). Asbestos. Washington, D.C.: U.S. Environmental Protection Agency. http://www2.epa.gov/asbestos. Accessed August 2014.

EPA (2014). Duct Sealing Brochure. Washington, D.C.: U.S. Environmental Protection Agency. http://www.energystar.gov/ia/products/heat_cool/ducts/DuctSealingBrochure04.pdf?9d1f-8c89. Accessed August 2014.

ICC (2006a) 2006 International Residential Code For One- and Two-Family Dwellings, Section G2439.4. Washington, D.C.: International Code Council.

ICC (2006b). 2006 International Fuel Gas Code, Section 614.5. Clothes Dryer Exhaust. Washington, D.C.: International Code Council.

ICC (2009a). International Residential Code Update, Section R202). Washington, D.C.: International Code Council.

ICC (2009b) International Fuel Gas Code; Appendix D: Recommended Procedure for Safety Inspection of an Existing Appliance Installation. Washington, D.C.: International Code Council.

ICC (2009c). 2009 International Residential Code For One- and Two-Family Dwellings: Chapter 3 - Building Planning; Section R315 Carbon Monoxide Alarms. Washington, D.C.: International Code Council.

ICC (2009d). 2009 International Residential Code For One- and Two-Family Dwellings: Chapter 24, Fuel Gas; Section G2407 Combustion, Ventilation and Dilution Air; G2407.6.2 One-

Permanent Opening Method. Washington, D.C.: International Code Council.

ICC (2009e). 2009 International Residential Code For One- and Two-Family Dwellings: Chapter 8, Roof-Ceiling Construction. Washington, D.C.: International Code Council.

NFPA (2006). NFPA 31, Standard for the Installation of Oil-Burning Equipment. Chapter 5, Air for Combustion and Ventilation. Quincy, MA: National Fire Protection Association.

The Energy Conservatory (2012). Minneapolis Blower Door Operation Manual for Model 3 and Model 4 Systems. Minneapolis, MN: The Energy Conservatory. http://www.energyconservatory.com/sites/default/files/documents/mod 3-4 dg700 new flow_rings_- cr_tpt__no fr_switch manual_ce_0.pdf. Accessed August 2014. 


\section{Appendix A: Attic Ventilation for Durability}

\section{Sample Work Plan-Inspection of the House}

Before developing the work plan, complete an exterior walk-around, an interior walk-through, and an attic investigation. If any of the following items are found during the inspection they must be dealt with before proceeding with the retrofit.

- The house attic has active knob and tube wiring.

- The house attic has vermiculite insulation.

- The house has natural draft appliances.

- The house attic has bathroom fans vented into the attic.

- The house has a leaking roof.

- The house attic has floorboards or other floor sheathing.

1. Exterior: As you complete the walk-around, note specifics such as size and location of the following items:

- Soffit vents

- Gable end vents

- Mushroom vent caps

- Plumbing stacks

- Combustion air intakes and exhausts

- Exhaust air vents

2. Interior: As you complete the walk-through, note specifics such as size and location of the following items:

- Attic access and type

- Dropped soffits

- Exterior wall perimeter length, kneewalls

- Two-story walls

- Bath fans in the ceiling

- Air supply vents through the ceiling

- Lighting fixtures in the ceiling, both recessed cans and standard lights

- Masonry and metal chimney pipe chases 
- Look for signs of a leaking roof. If the roof is leaking, it must be repaired before proceeding with the retrofit.

3. Attic: As you complete the attic investigation, note specifics such as the presence, size and location of the following items:

- Attic access type and size

- Floorboards or sheathing attached to the ceiling/attic floor framing

- Ceiling/attic floor joists perpendicular to roof rafters

- Attic vent baffles and exterior top plate

- Dropped soffits open to the attic

- Kneewalls

- Top plate joints

- Two-story walls

- Mechanical, electrical and plumbing penetrations

- Bath fans and venting

- Masonry and metal chimney pipe chases

- Ductwork.

Look for signs of a leaking roof, active knob and tube wiring, vermiculite insulation, bathroom fans ducted into the attic or kneewall, unvented kerosene heaters or gas fireplaces, and attic flooring. If any one of these are found, they must be repaired before proceeding with the retrofit. Attic flooring or floor sheathing prevents access to areas that need to be inspected and areas that need to be air sealed; therefore, it will need to be removed before work can proceed. However, the attic flooring or floor sheathing may also be providing an important structural function. Consult a qualified professional before removing floorboards or sheathing attached to ceiling/attic floor joists that are not parallel to roof rafters. Replicate the structural function of the attic flooring, if needed, before removing it. 


\section{Checklist and Work Plan}

Stop-Work Items

The house attic has active knob and tube wiring.

YES - The house must be rewired prior to the attic being air sealed and insulated.

NO - Proceed

The house attic has vermiculite insulation.

YES The vermiculite insulation may contain asbestos and must be removed prior to the attic being air sealed and insulated. Professional advice should be obtained.

YES - Contact your State Department of Health.

NO- Proceed

The house attic has bathroom fans vented into the attic.

YES - Bathroom fans must be vented to the outside prior to the attic being air sealed and insulated.

NO - Proceed

The house has a leaking roof.

YES - The leaking roof must be fixed prior to the attic being air sealed and insulated.

NO - Proceed

There is an unvented kerosene heater or gas fireplace.

YES - The unvented heater or fireplace must be vented or removed prior to the attic being air sealed and insulated.

NO - Proceed

The attic floor has floor boards or other floor sheathing.

YES - Professional advise should be sought to determine whether the flooring serves a structural function. If it does, the function must be replicated by other means

YES - before the flooring is removed to allow access for air sealing and insulating.

INTERIOR WALK THROUGH

1 - Locate the mechanical space within the home. Find the information tags on each of the appropriate appliances. Record the following information: Gas Furnace with Natural Draft Exhaust

$A=$ Btu Input

Gas Water Heater with Natural Draft Exhaust

$B=$ Btu Input

Gas Boiler with Natural Draft Exhaust

$\mathrm{C}=\mathrm{Btu}$ Input

Gas Fired Dryer

$D=$ Btu Input

2 - Totalize all Natural Draft Appliance Input

Total Btu of All Gas Fired appliances in mechanical space $Y=A+B+C+D$

Total Btu of All Oil Fired appliances in mechanical space $X=E+F+G$

Total Btu of All Gas Fired appliances in mechanical space $Z=X+Y$

3 - Check for Outdoor Combustion Air Supply Vent

If Combustion Air Supply Vent is Present

Diameter of Pipe

Number of Pipe (s) present

Pipe Material

Interior Location of Pipe

Outside location of Pipe and Height off of Ground

Oil Furnace with Natural Draft Exhaust

$E=\quad$ Btu Input

Oil Water Heater with Natural Draft Exhaust

$F=\quad$ Btu Input

Oil Boiler with Natural Draft Exhaust

$G=\quad$ Btu Input

Compare Diameter and Total Btu present with Table 1 or Table 2 if Area on-site is equal to or greater than the area required

*Always compare with Table 2 if any oil fired natural draft appliances are present

If Outdoor Combustion Air Supply Vent is Not Present or Undersized

A properly sized combustion Air Supply Vent must be Installed

Determine appropriate combustion air supply vent required from Table 1 and/or Table 2

Determine installation route for vent and approximate length required

- Check for Additional Indoor Air Vents if Oil Fired Natural Draft Appliances are Present and located in an Enclosed Spac

If Indoor Air Vents are Present

Area of vents $=A$

Grill material - Wood $(K=0.25)$ or Metal $(K=0.75)$

Effective Vent Area - EA $=A \times K \quad$ Example - for a metal 100sqin vent $-E A=100 \times 0.75=75$ sqin $E A=$

Compare this EA with the required effective area in Table 2.

If the area present does not meet the requirements of Table 2, additional venting area must be installed.

If Indoor Air Vents are Not Present or Undersized

Determine appropriate vent area required from Table 2

Determine installation location for vent(s)

5 - Check for Controlled Ventilation

Supply system - a properly sized outside air duct connected to the furnace or air conditioner

If a Supply system does not exist check for an exhaust system

Diameter of Pipe

Number of Pipe (s) present

Pipe Material

Location of Pipe

Outside location of Pipe and Height off of Ground

Damper Present and Functioning

Exhaust System

If an exhaust system or a supply system do not exist, one of either must be installed.

Number of Bathroom fans present

Bathroom fans exhaust to outdoors (Must be re-vented if vented into attics, kneewalls, conditioned crawlspaces, garages etc.)

Fans exhaust to unobstructed location

- Carbon Monoxide Detectors

Check for Operational Carbon monoxide detectors (test with test button) $\quad$ YES

Check Location of Carbon Monoxide Detectors and ensure they are in close proximity to Natural Draft Appliances.

If Carbon Monoxide Detectors do not exist, are improperly located, or do not function properly a Carbon monoxide detector must be installed 


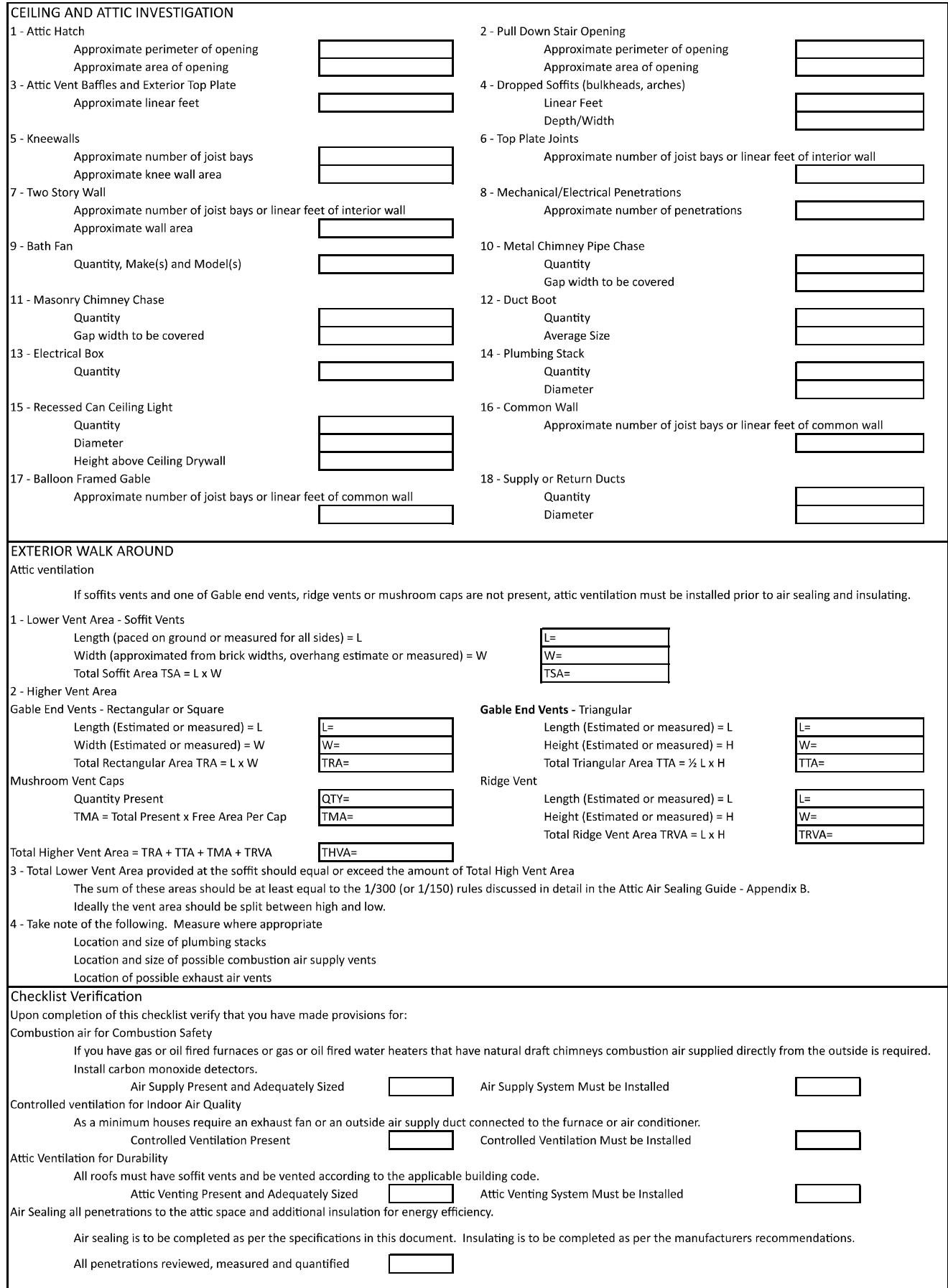




\section{Customer Communication}

Upon completion of the inspection and the checklist, provide a statement of work to the homeowner.

Report the findings of your inspection and describe the work required. Be sure to include any stop work items.

Example: For this home we will require additional venting to the mechanical room, a new bathroom fan that will supply the required ventilation, air sealing of the attic including all penetrations present, and additional insulation placed once the air sealing is complete.

If you are a qualified professional or have sub-contracted qualified professionals who are able to repair the stop-work items and to complete the job in full, inform the Homeowner that you will provide them with a quote to complete the work within a reasonable time period. If you do not have the capability to repair the stop-work items, inform the Homeowner that they will have to hire additional qualified professionals to complete the necessary tasks before you are able to complete your portion of the work.

Provide the Homeowner with a quote for the work that is to the best of your knowledge complete and contains all items that will require installation, repair or replacement. Be aware that while you are quoting the job that the Homeowner may have already had, or may plan to have another contractor also bidding on the job. If the Homeowner is presented with a much more thorough review of the home or an equal review of the home with a better quote, you may not be awarded the job. A complete and thorough review of the home with an accurate quote can help win the job. Provide this Guide and the completed checklist to the Homeowner.

Schedule the time required to complete with the Homeowner. The Homeowner may want to be present during the construction or have someone present to oversee the construction. Inform the Homeowner that the person present overseeing your work must be at least 18 years of age.

On completion of the work, remind the homeowner that any future work on the house involving a combustion appliance or powerful exhaust fan (e.g., kitchen exhaust greater than $300 \mathrm{cfm}$ ) must be provided with adequate combustion air or make-up air according to the building code.

\section{IMPORTANT}

The Federal Trade Commission's R-value Rule (16 CFR Part 460) specifies substantiation and disclosure requirements for thermal insulation products used in the residential market, and prohibits certain claims unless they are true. The primary disclosure required is the insulation product's "R-value." R-value is the numerical measure of the ability of an insulation product to restrict the flow of heat and, therefore, to reduce energy costs - the higher the R-value, the better the product's insulating ability. To assist consumers, the Rule requires sellers (including insulation manufacturers, professional installers, new home sellers, and retailers) to disclose the insulation product's R-value and related information, before retail sale, based on uniform, industry-adopted standards. This information enables consumers to evaluate how well a 
particular insulation product is likely to perform, to determine whether the cost of the insulation is justified, and to make meaningful, cost-benefit based purchasing decisions among competing products.

For more information, please see www.ftc.gov/energy. 


\section{Appendix B: Sample Calculations}

\section{Attic Ventilation}

The total net free ventilating area should not be less than $1 / 300$ of the area of the attic/roof space to be ventilated and ventilation openings should be located both high and low in the roof assembly. Lower ventilation openings should be provided in each rafter bay of the roof assembly. A minimum 1-in. space should be maintained between the

Definition: Net free ventilating area refers to the clear open area of a vent taking into account the restrictions of the vent screens and vent slots. For example most screened vents have a $60 \%$ free area. insulation and the roof sheathing and between the insulation and any roof vent openings.

The area of the attic/roof space to be ventilated is the area of the floor or ceiling that separates the attic/roof space from conditioned space. Therefore, minimum total net free ventilation area for an attic/roof space is equal to the area of the floor or ceiling beneath the roof assembly divided by 300 .

It is recommended that not more than 50 percent of the net free ventilating area be located high on the roof. These upper ventilation openings should be located at least 3 feet above the soffit or eave vent openings. The area of the attic/roof space is the sloped ceiling area in situations such as where the ceilings are applied directly to the underside of the roof rafters and where the attic/roof space is within scissor trusses.

Homes without roof overhangs or other accommodation for ventilation openings at the soffit or eave, should have a net free ventilating area of not less than 1/150 of the area of the ventilated attic/roof space. Refer to the example for 1:150 attic ventilation below.

\section{Example for 1:300 high/low attic ventilation}

Consider a house that is $30 \mathrm{ft}$ wide by $42 \mathrm{ft}$ long. The top floor ceiling is flat in this example so the area of the attic space is equal to the area of the foot print of the house.

The area of the ventilated attic space is therefore:

$30 \mathrm{ft} \times 42 \mathrm{ft}=1260 \mathrm{ft}^{2}$

The required total net free ventilation area is:

$1260 \mathrm{ft}^{2} / 300=4.2 \mathrm{ft}^{2}$

Converting $\mathrm{ft}^{2}$ to in. ${ }^{2}$, the required total net free ventilation area yields:

$4.2 \mathrm{ft}^{2} \times 144 \mathrm{in}^{2} / \mathrm{ft}^{2}=605 \mathrm{in}^{2}$ (note that the required area is rounded up to the nearest inch) 
Approximately $50 \%$ of the total net free ventilating area should be located in the upper portion of the roof, at least $3 \mathrm{ft}$ above the soffit or eave vents. The required net free ventilating area of the upper roof vents should be:

$0.5 \times 605$ in. $^{2}=303$ in. $^{2}$

The remainder of the required free ventilating area should be provided by soffit or eave vents so that the total required free ventilating area is achieved. It is important that the soffit or eave vents provide ventilation in each rafter bay.

\section{Example for 1:150 attic ventilation}

Considering the same $30 \mathrm{ft}$ by $42 \mathrm{ft}$ house only this time without soffit vents, eyebrow vents or low gable vents. If it is not possible to provide ventilation openings at the bottom of the roof assembly, then the required minimum free ventilating area is $1 / 150$ of the area of the attic/roof space to be ventilated.

The area of the ventilated attic space is:

$30 \mathrm{ft} \times 42 \mathrm{ft}=1260 \mathrm{ft}^{2}$

The required total net free ventilation area is:

$1260 \mathrm{ft}^{2} / 150=8.4 \mathrm{ft}^{2}$

Converting $\mathrm{ft}^{2}$ to $\mathrm{in} .^{2}$, the required total net free ventilation area yields:

$8.4 \mathrm{ft}^{2} \times 144 \mathrm{in}^{2} / \mathrm{ft}^{2}=1210$ in. $^{2}$ (note that the required area is rounded up to the nearest inch). 


\section{Appendix C: Material Specification}

Air Barrier (ABM) Any rigid or semi rigid material that does not allow air to pass through it. Examples: gypsum board, plywood/OSB, foam board, duct board (with a facing flame spread rating of 25 or less), sheet metal or dimensional lumber.

Relevant Test Methods: ASTM E2178 and E283

Fire Rated Sealant (FRS) Any sealant that is UL listed for use in any details requiring an approved fire rated sealant. Example: Sealing sheet metal ABM to a chimney.

Relevant Test Method: ASTM 814

Required Certification: UL1479

Insulation Any material which significantly slows down or retards the flow or transfer of heat. Building insulation types are classified according to form (e.g., loose-fill, batt, flexible, rigid, reflective, and foamed-in-place) or material (fiber glass, rock and slag wool, organic fiber, foam plastic)

Relevant Test Methods: ASTM C177, ASTM C518, ASTM C976, CFR Title 16, Part 460

Rigid Foam Rigid board material that provides thermal resistance. Foam plastic such as EPS, XPS, and polyisocyanurate.

Relevant Test Methods: ASTM C177, ASTM C518, ASTM C976, ICC-ES AC12, CFR Title 16, Part 460

Sealant Any flexible product which when applied to the join of two or more materials will adhere and permanently seal the joint to the passage of air. Examples: caulk, foam, and mastic.

Relevant Test Method: Foam sealants - ASTM C1642

Relevant Test Method: Acrylic, silicone, and urethane caulk - ASTM C-920

Required Certification: Water based duct sealant - UL 181A-M, UL 181B-M

Spray Foam Relevant Test Methods: "ICC-ES AC377, ASTM E84 CFR Title 16, Part 460"

Tape (for ducts) Required Certification: UL-181

Tape (for air sealing) Relevant Test Methods: ASTM D3330, ASTM D882

Weatherstripping Relevant Test Methods: ASTM C509 
